\title{
MURDOCH AND LEVINAS ON GOD AND GOOD
}

\author{
FIONA ELLIS
}

Heythrop College, University of London

\begin{abstract}
Murdoch and Levinas both believe that our humanity requires us to suppress our natural egoism and to be morally responsive to others. Murdoch insists that while such a morality presupposes a 'transcendent background', God should be kept out of the picture altogether. By contrast, Levinas argues that, in responding morally to others, we make contact with God (though not the God of traditional Christianity) and that in doing so we become more God-like. I attempt to clarify their agreements and differences, and I offer some criticisms of their conception of humanity, God, and the relationship between them.
\end{abstract}

\section{INTRODUCTION}

Iris Murdoch and Emmanuel Levinas are concerned with the question of what it is to be human, and their interest in it is ethical. The notion of humanity is understood as an ethical notion: to call someone 'inhuman' is an intensive way of saying that they are not morally responsive to others. This is not intended to explain why it is bad to be morally unresponsive to others. They are addressing those who already agree that it is bad to the point of inhumanity to rape or kill indiscriminately or to refrain from so doing only from cold self-interest.

They both believe that the more divine we are, the more human we become. ${ }^{1}$ This idea admits of various interpretations, some of which will offend the sensibilities of those who prefer an atheistic framework. Such objectors have nothing to fear from our protagonists: both have considerable sympathy for atheism and considerable antipathy for theism.

${ }^{1}$ I take this phrase from Nicholas Lash's wonderful paper "The Impossibility of Atheism”, in Theology for Pilgrims (Darton, Longman and Todd: London, 2008), 27. 
I shall, however, raise a further difficulty with this idea when we look more closely at their conception of humanity.

Agreements notwithstanding, their positive positions are harder to reconcile. They insist that being (fully) human involves standing in a relation to the Good, yet Levinas, unlike Murdoch, spells out this relation in God-involving terms. I shall argue that this disagreement is verbal, and it must remain to be seen whether Murdoch believes in God, whether moral realists believe in God, or whether Levinas is a closet atheist.

\section{BEING HUMAN}

Murdoch and Levinas's picture of human being is, at one level, profoundly bleak. Murdoch talks of the 'fat relentless ego' who desires to 'dominate, possess, devour and absorb the other', to 'subject him to the mechanism of (his) own fantasy'. ${ }^{3}$ Levinas refers to the monopolistic ego which conquers and dominates everything that stands in its way. ${ }^{4}$ They agree that an egoistic mode of existence is morally deficient because it precludes the possibility of a genuine ethical relation to another person - a relation which involves appreciating her independent reality. Murdoch says that 'fantasy (self) can prevent us ... from seeing another person,, that our direction of attention must be turned outward, away from the self and towards the other, ${ }^{6}$ and that this movement can 'bring us to what is good'. ${ }^{7}$ Levinas claims that the other exists 'outside of the hunger one satisfies, the thirst one quenches, and the senses one allays', ${ }^{8}$ that by relating to the other 'I am no longer able to have power', and that this relationship opens up the dimension of the ethical. ${ }^{10}$

2 "On 'God' and 'Good”, in The Sovereignty of Good (Routledge: London, I970), 52.

${ }^{3}$ The Fire and the Sun, (Oxford University Press: Oxford, I977), 36.

${ }^{4}$ See, for example, "Philosophy and the Idea of the Infinite", in Adrian Peperzak, To the Other (Purdue University Press: Indiana), 88-I2O.

5 "On 'God and 'Good", 70.

${ }^{6}$ Ibid., 59 .

${ }^{7}$ Ibid., 66.

8 "Philosophy and the Idea of the Infinite", II4.

${ }^{9}$ Ibid., IIO.

${ }^{10}$ Ibid. 
An egoistic mode of existence is also metaphysically deficient. It shields us from that aspect of reality to which we are responsive when we enter the dimension of the ethical - an aspect which provides an analogue for 'how things really are', and our responsiveness to which is required if we are to be fully human. Murdoch calls this dimension 'the real'." She claims also that realism, as the ability to perceive reality, is a 'moral achievement', and that it requires a 'suppression of the self'. ${ }^{12}$ True vision, she says, occasions right conduct. Plato's Symposium illustrates what happens when the ego fades and this vision is realized: we 'escape from the mean petty slavery of the particular case and turn towards the open sea of beauty.' ${ }^{13}$

Levinas agrees that the world of the personal ego is metaphysically deficient, and he likewise cites Plato in his account of the shift required as we move from the limiting framework of the egoist to one which involves an appreciation of the Good. He expresses this by saying that it situates the Good above Being, and he cites Plato's Phaedrus as the ancestor of this position. ${ }^{14}$ Like Murdoch, he is gesturing towards a conception of reality which is irreducibly moral, and essentially refers to the needs and desires of others. We are moved towards an 'ethics of responsibility for the Other'; ${ }^{15}$ we are propelled towards Goodness. ${ }^{16}$

\section{GOD}

Murdoch holds that morality is unavoidable, that we forsake it only at the cost of our humanity. Morality is also central to genuine religion, but both religion and morality are compromised when defined in God-

\footnotetext{
11 “On 'God' and 'Good', 59.

${ }^{12}$ Ibid., 66.

${ }^{13}$ This claim is to be found at $2 \mathrm{TOD}$ of The Symposium.

14 "Philosophy and the Idea of the infinite", Io6.

15 "The Thinking of Being and the Question of the Other", in Of God Who Comes to Mind, trans., Bettina Bergo (Stanford University Press: Stanford, CA, I998), I2I.

16 "God and Philosophy", in Of God Who Comes to Mind, 69.
} 
involving terms. ${ }^{17}$ She recommends that we 'remove' the traditional notion of God. ${ }^{18}$

'God' is the name for a supernatural person. It makes a difference whether we believe in such a person, as it makes a difference whether Christ rose from the dead. These differences do not generally, or do not yet, affect whether or not people are virtuous. ${ }^{19}$

Christianity can perhaps continue without this personal God, and 'without beliefs in supernatural places and happenings, such as heaven and life after death'. She approves of the way in which religion 'is detaching itself from supernatural dogma'. ${ }^{20}$

This implies that we should abandon 'God' for 'Good', and allow that religion is:

a mode of belief in the unique sovereign place of goodness or virtue in human life. One might put it flatly by saying that there is something about moral value which goes jusquiau bout. It must go all the way, to the base, to the top, it must be everywhere... It adheres essentially to the conception of being human, and cannot be detached; and we may express this by saying that it is not accidental, does not exist contingently, is above being. ${ }^{21}$

So we get the following picture: God is a supernatural person, and belief in God involves a commitment to supernatural dogma. Such belief is supposed to make some kind of difference, but it makes no moral difference, and is irrelevant therefore to what it is to be human. The dimension of reality to which God talk refers is 'detached' from human reality, because there is no evidence for the existence of such a being. It is also detached from Good because Good is internally related to human reality, and the existence of a supernatural being could have no bearing on moral conduct. As Murdoch insists, the moral person is good 'for nothing'. Being good 'for something' would involve some non-moral motive - the desire for

17 "The Ontological Proof", in Metaphysics as a Guide to Morals (Chatto and Windus: London, 1992), 418.

${ }^{18}$ Ibid.

${ }^{19}$ Ibid., $4 \mathrm{I} 9$.

${ }^{20}$ Ibid., 425 .

${ }^{21}$ Ibid.,. 426 
salvation, for example - a motive which would be part and parcel of the egoism which the reference to goodness was intended to break. ${ }^{22}$ Small wonder that Murdoch is happy to assume that there is no God, ${ }^{23}$ and to defend a conception of religion and morality which dispenses with Him.

Karl Rahner attacks the kind of God taken for granted by Murdoch:

That God really does not exist who operates and functions as an individual existent alongside other existents, and who would thus as it were be a member of the larger household of all reality. Anyone in search of such a God is searching for a false God. Both atheism and a more naïve form of theism labour under the same false notion of God, only the former denies it while the latter believes that it can make sense of it. Both are basically false: the latter, the notion that naïve theism has, because this God does not exist; and the former, atheism, because God is the most radical, the most original, and in a certain sense the most self-evident reality. ${ }^{24}$

From Rahner's perspective, Murdoch has a faulty conception of God. She supposes that God is just a god - a being on the same level as any other being in reality. More powerful, perhaps, but vastly inferior to the goodness which, like Rahner's God, is 'the most original, and in a certain sense the most self-evident reality', and that without which we would cease to be human. ${ }^{25}$

Rahner's position is now a commonplace in theology, perhaps it always was. Nevertheless, a long line of theologians and philosophers have sought to rescue us from the kind of misconception presupposed by Murdoch, and one such figure is Levinas. Levinas riles against approaches to the question of God which set it apart from the question of what it is to be human. They make the God question into something highly abstract, and sever the connection between religion and ethics. This leads one to suppose that the question of God is a theoretical question, and that

${ }^{22}$ Compare: 'Almost anything that consoles us is a fake'. (“On 'God' and 'Good”, 59.

23 "On 'God' and 'Good', 75.

${ }^{24}$ Foundations of Christian Faith: An Introduction to the Idea of Christianity, trans. William V. Dych, (Darton, Longman and Todd: London, I978), 63.

${ }^{25}$ Ibid., p.63. 
religion is a matter of theorizing about God. Wedded to the idea that God is divorced from anything remotely human, this can quickly lead to the conclusion that $\mathrm{He}$ does not exist, and that it does not matter much anyway (Murdoch). Even if we resist this sceptical response in favour of continued theoretical investigation, this can only compromise an idea which, for Levinas, is fundamental, namely, that God cannot be grasped by human thought. Finally, this approach ends up ignoring the question how we should treat others.

Even if we distrust a theoretical approach to God, this can give rise to an equally problematic alternative: surrender to mystical abandon. Levinas has no time for this 'human elevation'. 'The Sacred that envelops and transports me is a form of violence', that is, it is 'contrary to the education of man'. ${ }^{26}$ It is violent because it 'annuls the links between persons', and leads the individual to 'founder' in a false form of ecstasy in which feeling is given precedence and 'the conditions for action and effort' are annulled. ${ }^{27} \mathrm{It}$ is contrary to the education of man because it leads one yet again to ignore the demands of others. There can be no relating to God in such a context, and no possibility therefore of becoming fully human: it is an ecstasy which [violently] tears man away from his essence, from his human nature. ${ }^{28}$

A related criticism of surrender to God by feeling alone is that this 'consolation of divine presence' casts humanity in the role of a helpless child who turns to God in the way that one might turn to a parent. ${ }^{29}$ Again, the requirements of ethics are silenced, and God's nature is seriously compromised - he becomes an inhabitant of 'the child's heaven', a consoling father figure who satisfies our need for security. Levinas concurs with Murdoch's complaint that 'almost anything that consoles us is a fake'. A God of this kind will never live up to our expectations. Prayers will go unanswered, consolation will give way to frustration, and atheism will follow quickly in its wake. For Levinas this atheist response

26 "A Religion for Adults" in Difficult Freedom: Essays on Judaism, trans. Sean Hand, (The John Hopkins University Press: Baltimore), I4.

${ }^{27}$ Ibid, 15 .

${ }^{28} \mathrm{Ibid}, \mathrm{I5}$.

29 "Loving the Torah more than God", trans. Sean Hand, in Difficult Freedom: Essays on Judaism, I43. 
is a positive step: we are freed from an infantile conception of God, ${ }^{30}$ and the way is paved towards a religion which accords due weight to the ethical - a 'religion for adults'.

So Murdoch and Levinas have much in common. They reject a conception of God which sets Him apart from the realm of the ethical and which makes His existence irrelevant to the question how we are to fulfil our humanity. Both attest the liberating effect of atheism. For Murdoch, it accepts that there is no God, and, unsurprisingly, she is happy to embrace such a standpoint, believing that it holds out the prospect of defining a conception of humanity which can give more adequate expression to the insights which drive traditional theism. However, she warns of the dangers of a natural consequence of atheism - 'a stripped and empty scene ${ }^{31}$ in which morality 'is pictured without any transcendent background'. ${ }^{32}$ On this way of thinking - typical of existentialist atheism - morality is 'essentially centred on the individual', 33 and 'however grandiose the structure may be in terms of which a morality extends itself, the moral agent is responsible for endowing this structure with value'. ${ }^{34}$ The result is a 'false transcendence' in which 'value' is attached to the human will. ${ }^{35}$ On her preferred alternative, the individual is 'held in a framework that transcends him, and towards which he is tentatively moving, ${ }^{36}$ and discovering what is morally good is a matter of discovering that reality, and 'integrating himself with it', ${ }^{37}$ however 'impossibly difficult' that task might turn out to be.

Here then is Murdoch's account of the available alternatives. First, we have the God-involving option. This panders to our all too egoistic tendencies and makes no sense of our capacity to be good. Second, we have an atheist option which has a similar dehumanizing effect. It involves a commitment to the same egoistic self, and assumes likewise that Good,

\footnotetext{
${ }^{30}$ Ibid.

31 "Metaphysics and Ethics", in Existentialists and Mystics (Chatto and Windus: London, 1997), 63 .

${ }^{32}$ Ibid.

${ }^{33}$ Ibid., 68.

${ }^{34}$ Ibid., 7 I.

35 “On 'God' and 'Good”, 58.

36 "Metaphysics and Ethics", 70.

${ }^{37}$ Ibid.
} 
if it enters the picture at all, must be constructed from the resources of this self. Finally, her own preferred standpoint is that in which the self inhabits a moral framework which is not of its own making and which grants it the possibility of transcending its egoistic preoccupations in order to acknowledge and to act upon the moral demands of others.

Levinas's take on atheism is rather more complex. We must reject the conception of God which Murdoch discards. However, he would question Murdoch's claim that there is no God on three scores. First, it is the response of one who is simply rejecting an infantile conception of God. Second, this rejection can lead the way to the true God. Third, it is only by embracing the true God that we shall vindicate the kind of position which, for Murdoch, can be articulated only by reference to the idea of goodness. For Levinas, we must move beyond the egoistic framework which remains in place provided that God is no more than a consoling father in the sky, and acknowledge our responsibilities to others. This movement requires that the self initially finds himself 'outside of God', 38 and cast back upon himself. This is the starting-point for genuine ethical engagement (no more passing the buck to an interventionist God). Yet, he allows also (once more in agreement with Murdoch) that this movement outward is not inevitable, that one can remain embroiled in a mode of existence in which egoistic concerns are paramount. He assigns Heidegger to this level, citing his analysis of care in Being and Time - an analysis which, as Levinas sees it, ignores the ethical dimension. ${ }^{39}$

So Murdoch and Levinas agree that reference to God can impede moral development. They agree also that there are atheist alternatives which have a similar dehumanizing effect, and that a satisfactory position must give due weight to our moral relations to others. Murdoch believes that this becomes available once we trade in God for Good, whilst acknowledging that this move doesn't come easy. ${ }^{40}$ Levinas agrees that the comforting position is the easier one, but describes his preferred

${ }^{38}$ Totality and Infinity:An Essay on Exteriority, trans. Alphonso Lingis (Martinus Nijhoff: The Hague, 1979), 58.

${ }^{39}$ See Existence and Existents, trans. Alphonso Lingis, (Martinus Nijhoff: The Hague, I978), 44 .

40 "The Sovereignty of Good Over Other Concepts", in The Sovereignty of Good, Ioo. 
alternative in God-involving terms: it requires trading in a false god for the true God.

\section{MURDOCH ON GOOD}

Murdoch has more time for God than she sometimes lets on. She claims that moral philosophy should retain a central concept which has all of the characteristics we associate with God, where God 'was (or is) a single perfect transcendent non-representable and necessarily real object of attention'. ${ }^{41}$ What is a real object of attention? How does it relate to Murdoch's claim that by attending to it we attain a 'true vision' of reality? The metaphor of vision is liable to mislead, and it is easy to conclude that Murdoch has in mind the self-enclosed mystical abandon which Levinas rejects. She insists, however, that true vision occasions right conduct, and that what she is getting at belongs to the moral life of the ordinary person. It is perfectly fine to say that the background to morals is 'some sort of mysticism', provided that this is understood aright. It involves no 'complicated secret doctrine', it is not 'removed from ordinary life', and there is no 'elite of mystics'. It is an 'unesoteric mysticism'42 involving 'a non-dogmatic essentially unformulated faith in the reality of the Good'. ${ }^{43}$ This faith resists strict proof, but becomes intelligible and defensible insofar as we can relate to others in moral terms. ${ }^{44}$

What of Murdoch's claim that the object of attention is transcendent? She tells us that the idea of the transcendent belongs to morality 'in some form or other', but is difficult to interpret and readily assumes false forms. ${ }^{45}$ We have already considered the false forms at work when the transcendent assumes the guise of a consoling God, or when value is taken to be a construction of the individual human will. But what is true transcendence? Murdoch's discussion operates on several levels. One theme is that, in moral contexts, attention is directed away from the self

\footnotetext{
41 “On 'God' and 'Good', 55.

42 "The Sovereignty of Good Over Other Concepts", 92.

43 “On 'God' and 'Good”, 74.

${ }^{44}$ Ibid., 74 .

${ }^{45}$ Ibid., 58 .
} 
and towards the other. Responsiveness to the other furnishes one sense in which talk of transcendence might be appropriate, that we can transcend or move towards another person, and in doing so, leave egoistic concerns behind. Furthermore, insofar as the world of the egoist is limiting and not 'fully real', such transcendence leads us away from a false reality, but not into some weird supernatural realm. We simply leave behind the self-enclosed world of the egoist.

What of the idea that the Good towards which we are transcending is itself transcendent? Murdoch says: "'Good is a transcendent reality' means that virtue is the attempt to pierce the veil of selfish consciousness and join the world as it really is. ${ }^{46}$ It means no such thing, of course, but we can read between the lines and discern what it might mean to say that Good is transcendent. It transcends the realm of selfish consciousness, which means that it cannot be constructed from such a level. The idea that Goodness transcends the realm of selfish consciousness clarifies some other things Murdoch says about Goodness, for example, that it is not in this world, and that it is 'incorruptible'. ${ }^{47}$ It is not in this world since it does not belong to the realm of selfish consciousness, and it is incorruptible because it resists all attempts to be possessed or destroyed.

Elsewhere Murdoch suggests a more radical interpretation of the claim that Goodness is not in this world. She claims that it is 'to some extent mysterious' ${ }^{48}$, that it is 'not visible', ${ }^{49}$ and that 'it cannot be experienced, even when we see the unselfish man in the concentration camp. ${ }^{50}$ She then asks: 'what is it for someone who is not a religious believer and not some sort of mystic, to apprehend some separate 'form' of goodness behind the multifarious cases of good behaviour?" ${ }^{51}$ The implication now is that Goodness transcends not merely selfish consciousness but also the dimension in which right conduct finds expression. What could this mean? Murdoch is clear enough about what it could not mean. This separate form of Goodness is not to be comprehended in the terms

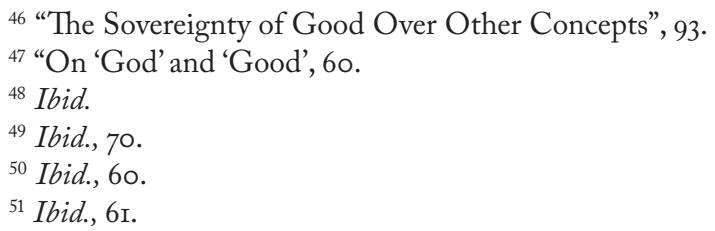


assumed by the religious believer, treating it as a supernatural person. It is not the object of an esoteric mystical apprehension. It is not, however, visible. Goodness's invisibility puts paid to the idea that it could be an object of mystical awareness, but what kind of apprehension is at issue? Murdoch claims:

The only genuine way to be good is to be good 'for nothing'....That 'for nothing' is indeed the experienced correlate of the invisibility or non-representable blankness of the idea of Good itself. ${ }^{52}$

We can begin to see what is going on here by focusing upon the idea of being good 'for something', of being good for some purpose specifiable in non-moral terms. For example, I help you out because you've promised me a nice reward, or because I think God has promised me an even nicer reward. In such a case Goodness becomes, if not visible, then at least something comprehensible. It is a matter of getting rewards, pleasure, or whatever. By contrast, when we are good 'for nothing', these explanations are unavailable, and all that we can say is that we are good for the sake of Goodness. Once we reach this point, we are led towards the idea that Goodness itself is invisible and non-representable.

Much of this recalls G.E. Moore's arguments about the indefinability of 'Good', and one interpretation of these arguments is that they reject any attempt to analyse Goodness in non-moral terms. However, this allows the possibility of elucidating Goodness in moral terms, and Murdoch herself seems happy to concede this, when she talks of how we might clarify our understanding of Goodness by spelling out the relations between different virtues. ${ }^{53}$ However, she clearly wants to go further, and uses Moore to illustrate her position:

Good is indefinable... because of the infinite difficulty of the task of apprehending a magnetic but inexhaustible reality. Moore was in a way nearer to the truth than he realized when he tried to say both that Good was there and that one could say nothing of what it essentially was. ${ }^{54}$

\footnotetext{
${ }^{52}$ Ibid., 7 I.

${ }^{53}$ Ibid., $57^{-8}$.

54 "The Idea of Perfection", in Existentialists and Mystics, 333.
} 
Clearly, the force of the claim that we can say nothing about Goodness is not simply that it cannot be captured in non-moral terms, but that its very nature exceeds any attempt to grasp it. Elsewhere she says:

There is a magnetic centre. But it is easier to look at the converging edges than to look at the centre itself. We do not and probably cannot know, conceptualise, what it is like in the centre. ${ }^{55}$

Goodness is unknowable in itself, but we respond to its magnetic pull and resist the more consoling alternatives thrown up by the egoistic self. We respond to its magnetic pull by relating to others in moral terms, and then we have an apprehension of the Good. This apprehension is 'apprehension of the individual and the real'. ${ }^{56}$ For Murdoch, "the individual" is the central concept of morality', and given the emphasis she places upon our moral relations to others, we naturally suppose that she means human individuals. This is borne out by some of her remarks. Having said that morality involves attention to individuals, she offers 'human individuals' as a case in point.$^{57}$ However, the individual qua central concept of morality clearly refers also to the 'separate form of goodness which lies behind the multifarious cases of good behaviour', this 'single supreme value concept' which orders and unifies our moral world, ${ }^{58}$ and exerts its authority from an unknowable and invisible 'beyond'..$^{9}$

Murdoch draws a threefold distinction between a self-enclosed realm of egoistic consciousness, an ethical dimension of behaving well towards others, and a separate form of Goodness. The second two levels cannot be reduced to or constructed from the first, but the relation between the second and third levels is less clear. A separate form of Goodness behind our multifarious good behaviour suggests that Goodness is metaphysically distinct from the second level of reality. She insists, however, that it is not an object of experience or thought, and can be glimpsed only via our ethical relations to others. So, apparently, it is metaphysically distinct

55 "The Sovereignty of Good Over Other Concepts", , soo. See also "On 'God' and 'Good”, 75 .

56 "The Idea of Perfection", in Existentialists and Mystics, 333.

${ }^{57}$ Ibid, 334 .

58 "On 'God' and 'Good", 57-58.

${ }^{59}$ Ibid., 62. 
from the second level of reality, but epistemologically dependent upon it. Our knowledge of it, such as it is, is irreducibly practical: true vision occasions right conduct.

\section{LEVINAS ON GOD}

'The vision of God is a moral act. This optics is ethics'.$^{60}$ In saying this, Levinas offers a version of Murdoch's claim that 'true vision occasions right conduct'. Like Murdoch, he dissociates talk of vision from mystical flights of fancy, insisting that the central concept of morality - God - can be apprehended only via our ethical encounters with others. That this mode of apprehension can never do complete justice to the nature of God is a necessary and welcome corollary of God's transcendence.

Like Murdoch, he deploys several notions of transcendence. The first is our moving or transcending towards a dimension of reality in which we are morally responsive to others. This movement does not have its origin in selfish consciousness whose 'totalizing' constructions are pitched at the level of 'being'. Rather, it is effected from without, from a realm which is 'otherwise than being', 'infinite', and 'ethical', ${ }^{61}$ and our responsiveness to which liberates us from the clutches of egoism.

The idea that this new dimension of reality is 'infinite' and 'otherwise than being' introduces a second notion of transcendence: that the reality towards which we are moving is itself transcendent. We recall that Murdoch deploys two notions of transcendence in this further sense, the first referring to an ethical dimension beyond selfish consciousness, the second referring to something beyond this moral dimension - Goodness in itself. It is here that Levinas seems to part company with Murdoch. First, he denies that there is anything beyond the level of moral engagement with others, whether a separate form of Goodness or a separate God, and he applies the descriptions which Murdoch applies to Good - infinite, invisible, etc. - to the human other. Levinas has three reasons for denying

60 "For a Jewish Humanism", trans. Sean Hand, in Diffcult Freedom: Essays on Judaism, op.cit., 275 .

${ }^{61}$ Existence and Existents, $3 \mathrm{I}$. 
that God is to be set apart from the realm in which we interact morally with others. It compromises the reality of God, it severs the connection between religion and ethics, and it compromises our humanity. It sounds odd to say that the reality of God is compromised if $\mathrm{He}$ is taken to be distinct from the realm in which we interact morally with others. It would be natural to protest that His reality is preserved only by maintaining this distinction, and the alternative reduces religion to ethics without remainder.

Levinas is not seeking to reduce religion to ethics if this means that ethics involves no reference to God. However, he believes that it is essential that God is not set apart from the ethical realm, as He is when treated as the Supreme Being who can be apprehended in terms which bear no relation to this realm. Such treatment puts God at the service of egoistic consciousness - he becomes, at best, a God for us; the apprehension it presupposes, insofar as it ignores aspects of our being which come into play when we become morally responsive to others, profoundly dehumanizes us. It is only by becoming morally responsive to others that we fulfil our humanity and stand in a proper relation to God:

I approach the infinite insofar as I forget myself for my neighbour who looks at me.... A you is inserted between the I and the absolute He. ${ }^{62}$

"Going towards God" is meaningless unless seen in terms of my primary going towards the other person. ${ }^{63}$

Without the significance they draw from ethics, theological concepts remain empty and formal frameworks. ${ }^{64}$

God is not a something to be apprehended in non-moral terms, but it doesn't follow that he is nothing. We 'go towards God' by going towards

${ }^{62}$ Collected Philosophical Papers, ed. Alphonso Lingis (Martinus Nijhoff: The Hague, 1987), $72-3$.

${ }^{63}$ Face to Face with Levinas, trans. Richard Cohen (University of New York Press: Albany, NY, I986), 23.

${ }^{64}$ Totality and Infinity: An Essay on Exteriority, 79. 
the other person: 'a you is inserted between the I and the absolute He'. This model seems bound to fall short of taking us all the way to God. Not for Levinas, however, for he characterizes the other in terms which eliminate this distance. How is this supposed to work?

\section{LEVINAS ONTHE OTHER}

The moral relationship in which I stand towards the other 'puts me into question, empties me of myself', ${ }^{65}$ by releasing me from the confines of egoism. This disruption of the self occurs when I encounter the face of the other, and 'the dimension of the divine opens forth in the human face'. ${ }^{66}$ Why the face of the other? Levinas is not interested in physical appearance, but in the way in which the other:

(o)ppose(s) himself to me beyond all measure, with the total uncoveredness and nakedness of his defenseless eyes... Here is established a relationship with the absolute Other, with the resistance of what has no resistance, with ethical resistance... We call a face the epiphany of what can thus present itself directly, and therefore also exteriorly, to an I. ${ }^{67}$

The notion of the face captures the sense in which the other exists not simply as someone to be used or possessed, but, rather, as someone who forbids such treatment. Our encounter with the other involves a moral awakening in which I discover my responsibility for the other: 'I see myself obligated with respect to the Other'. ${ }^{68}$

The idea that I am obligated with respect to the other is intended to have important implications for a proper understanding of God and man. We recall that the picture of God as an indulgent father figure not only compromises His reality but our humanity too, by making us into helpless children who take no responsibility for ourselves and for others. Levinas counters this with a God who 'renounces all aids to manifestation,

${ }^{65}$ Basic Philosophical Writings, ed., Adriann Peperzak, Simon Critchley, Robert Bernasconi, (Indiana University Press: Bloomington, IN, 1964), 52.

${ }^{66}$ Totality and Infinity: An Essay on Exteriority, I78.

67 "Philosophy and the Idea of the Infinite", IIO.

68 "A Religion for Adults", 2I-2. 
and appeals instead to the full maturity of the responsible man'. ${ }^{69} \mathrm{We}$ can fulfil our humanity only if God does not 'manifest himself in any way as a help' or assume our 'duties and responsibilities' ${ }^{70}$ So the true God does not manifest Himself in any way as a help, and can be approached only via moral relations with others. The other is 'invisible', ${ }^{71}$ the 'vision of the face is not an experience, ${ }^{72}$ and 'to see a face is already to hear 'you shall not kill'. ${ }^{73}$ The other is 'situated in the dimension of height, in the ideal, the Divine, and through my relation to the Other, I am in touch with God'. ${ }^{74}$

It begins to sound as if the other just is God. Yet if this is so, what of the 'you' inserted between the 'I' and the 'absolute He'? If the 'you' just is God, the step from human other to God is surely eliminated. Then we end up compromising the reality either of God - by making Him human - or of the human other - by making him God. The first alternative suggests that Levinas has reduced religion to ethics, and that he differs from Murdoch only in the sense that he has transposed her descriptions of Goodness on to the human person. The second alternative suggests that he has inflated ethics into religion, and left us with nothing but a theological analogue of Murdoch's separable form of Goodness.

When Levinas tells us that the vision of the face is not an experience, he follows this up with the claim that it is 'a moving out of oneself, a contact with another being and not simply a sensation of self'. So, the force of saying that the other is invisible is to lend emphasis to this outward movement and to the moral significance that it bears - to see a face is already to hear 'you shall not kill'! As Murdoch herself agrees, true vision can never simply stare.

Even if true vision does not stare - whether at the face of the other, Goodness itself, or God Himself - questions remain: how does my relation to the other put me in touch with God? Clearly Levinas is not claiming that the other grants me a beatific vision of God. So ethics

\footnotetext{
69 "Loving the Torah More Than God", I43.

70 "A Religion for Adults", 20.

${ }^{71}$ Totality and Infinity: An Essay on Exteriority, 5 I.

72 "Ethics and Spirit", trans. Sean Hand, in Difficult Freedom: Essays on Judaism, Io.

${ }^{73}$ Ibid., 8.

74 "A Religion for Adults", 17 .
} 
is not inflated into religion in this sense. Nor would it make sense to say on his behalf that the other just is God. For not only does he insist upon the fundamental difference between Creator and created, but he describes the other in terms which emphasise not just to such God-like attributes as 'height' and 'invisibility', but equally those which express her vulnerability and neediness. The other for whom I am responsible is an ordinary human being.

So, the other does not put me in touch with God in any of these ways. Rather, she opens up a horizon in which I become morally responsive and responsible. It is only at this point that the 'God of heaven' becomes accessible, and does so 'without losing any of His transcendence' and 'without denying freedom to the believer'. ${ }^{75}$ The idea that God becomes accessible only via our moral relations to others shows that our relation to Him can never be direct and can only be ethically mediated. A direct relation with God would compromise His transcendence, and it would imply that we can be in communion with God whilst ignoring our moral responsibilities. We ignore these responsibilities only at the cost of compromising our humanity, and our humanity is compromised the moment we relate to a less than transcendent God. We can now appreciate the force of his claim that God - the true God - becomes accessible without losing any of His transcendence and without denying freedom to the believer.

Although Levinas rejects any attempt to bring God down to earth, his characterization of what it is to be truly human narrows the gap between God and man in a further respect. For he implies that, in our ethical encounters with others, we ourselves become more God-like: an equality is established 'between God and man at the very heart of their disproportion'. ${ }^{76}$ Talk of equality between God and man makes it look as if Levinas again risks undermining the distinction between God and man. Thus our responsibility for the other involves 'the transubstantiation of the Creator into the creature', ' $(t)$ he ' $I$ ' is the one who, before all decision, is elected to bear all the responsibility for the World'. ${ }^{7}$ He insists also

\footnotetext{
${ }^{75}$ Ibid.,18.

76 "Loving the Torah More Than God", I45.

77 "A Man-God?", trans. Michael B. Smith, in Entre Nous, (Continuum Press: London, 2006), 5 ०.
} 
that this responsibility cannot be annulled: 'The world in which pardon is all-powerful becomes inhuman'. ${ }^{78}$ Such talk seems to turn the subject into God. It also recalls certain existentialists, whose stance Murdoch calls 'an irresponsible and undirected self assertion'. But the qualification that the equality of God and man is established at the heart of their disproportion rules out a straightforward identification of the two, and differentiates Levinas from Murdoch's existentialist. But how then is it to be interpreted? And can it be squared with his insistence- shared by Murdoch - that the idea of an incarnate God is a scandal? ${ }^{79}$

For Levinas, the God of Christianity is a false, indulgent God who assumes our duties and responsibilities, and encloses us in our wickedness. ${ }^{80}$ The Incarnation throws up someone who takes responsibility for our sins, guarantees salvation by proxy, and leaves us to bask in our inhumanity. The interpretation is massively flawed, ${ }^{81}$ but it explains instantly why he rejects such a vision, and guides us towards an understanding of his own preferred take upon the idea of an incarnate God. The essential requirement is that our status as morally responsible beings be accommodated, and it is met with the claim that we "bear all the responsibility for the world'. This sounds terribly austere, and I shall consider some related worries in the following section. For the moment, it suffices to note that this austere vision 'in no way leads to the inhumanity of despair', because God 'is patient...lets time pass, awaits the return of man, his separation or regeneration.' But this regeneration must take place 'without the intervention of extrahuman factors other than consciousness of the Good, and the Law'. ${ }^{82}$

Where does this leave the idea that the creator is transubstantiated into the creature? By assuming our responsibilities and offering ourselves up to the service of others - even to the point of self-sacrifice - we become

78 "A Religion for Adults", 20.

${ }^{79}$ See Michael Purcell, Levinas and Theology (Cambridge University Press: Cambridge, 2006), I58-162, for a helpful discussion of Levinas's conception of incarnation.

80 'A New Version of Jesus Narrated by the Wandering Jew', trans. Sean Hand, in Difficult Freedom, I04.

${ }^{81}$ See Frans Jozef Van Beeck, Loving the Torah more than God: Toward a Catholic Appreciation of Judaism, (Loyola University Press: Chicago), part III.

82 "A Religion for Adults", 20. 
equal partners with God. Not by becoming God, but by becoming more like God, and in becoming more like God we become truly human. In this sense Levinas is committed to the idea that the more divine we are, the more human we become.

\section{GOD AND HUMANITY, AGAIN}

The idea that we become more God-like by giving ourselves to others seems to have important implications for an understanding of God. For our divinity, such as it is, is now a matter of giving - of being there for others: 'I am for (the Other)'. ${ }^{83}$ Now if self-giving makes us more like God, then the obvious conclusion is that God Himself is the supreme giver. Not, of course, in the sense that He gives out little prizes from on high, but in the sense that He gives Himself. What could this mean?

Nicholas Lash has argued that this way of thinking about God leads us away from the temptation to suppose that $\mathrm{He}$ is a thing, and expresses the idea that, in Him, the distinction between 'is' and 'does' gains no application: ${ }^{84}$ 'the holy mystery of God simply is the giving, the uttering, the breathing, that God is said to be and do'. ${ }^{85}$ Lash cites God's meeting with Moses at the burning bush, and God's response when asked 'Who shall I tell them sent me?' God's reply is 'I am who I am'. It is generally agreed that this reply is not to be interpreted in ontological terms, if this would imply that God is some kind of being. Another suggestion - taken seriously by Franz Rosenzweig - is that it is best translated as 'the onewho-is-there' i.e. there for us, coming towards us. ${ }^{86}$ This interpretation makes sense of God's earlier claim 'you cannot see my face'. ${ }^{87}$ It explains also why this meeting assumes such importance for Levinas, and why

83 "Ethics and Spirit", 7.

84 'The Impossibility of Atheism', 23.

${ }^{85}$ Ibid.

${ }^{86}$ This is the position taken by Franz Rosenzweig in his 'A Letter to Martin Goldner', in M. Buber and F. Rosenzweig: Scripture and Translation, trans. Lawrence Rosenwald with Everett Fox (Indiana University Press: Bloomington, I994). Quoted in Janet Soskice, The Kindness of God, (Oxford University Press, Oxford, 2007, I74.

${ }^{87}$ Exodus 33: 20. 
he turns to it in discussing God's invisibility and unknowability. ${ }^{88}$ But what more can be said about God's movement towards us? How is this movement to be related to our moral movement towards others? And how does all this fit with Levinas's claim that we can know Him only via this moral movement?

That God moves towards us, when coupled with the idea that we glimpse this movement only by responding morally to others, suggests two things. First, we are capable of partaking in this movement; second, the movement is irreducibly moral. Our partaking in this movement amounts to our becoming more God-like, and this lends further substance to the idea that God is a giver. God gives Himself to us in the sense that He makes us more God-like, and we become more God-like, and hence, more in touch with God, insofar as we become morally responsive beings.

We can agree that a human being should be morally responsive to others. However, both Murdoch and Levinas imply that this responsiveness requires a total suppression of the self, where this seems to rule out the possibility of having any concern for our own well-being. They suggest that a proper human being is a total giver, rather being a mixture of giver and taker. This idea is difficult to accept. A total suppression of the self would leave nothing remaining but the activity of giving - a consequence which is difficult to square with the fact that those who do good deeds usually want to do them themselves. ${ }^{89}$ If a total giver is no more human than the mixture of giver and taker, there are important implications for our understanding and assessment of the claim that the more divine we are, the more human we become. For, assuming that God is a total giver, this claim must be rejected: we become human by becoming more divine only up to a point.

One alternative is to reject the assumption that God is a total giver. It is of fundamental importance to Levinas that God does not reduce

${ }^{88}$ See, for example, "Revelation in the Jewish Tradition", in The Levinas Reader, ed. Sean Hand (Blackwell: Oxford, I989), 204.

${ }^{89}$ Compare also Benedict XVI: 'Man cannot always give, he must also receive'. Deus Caritas Est, Encylical Letter, given on December 25, 2005. Available at http://www.vatican. va/holy_father/benedict_xvi/encyclicals/documents/hf_ben-xvi_enc_20051225_deuscaritas-est_en.html 
people to dependency. God retains the distance required for us to do the required moral work, he allows us to stand on our own two feet and assume responsibility for self and world. This provides one way of denying that God is a total giver. And it has important implications for what is required if we are to be God-like in our dealings with others. We become God-like to the extent that we withhold goods from others which would reduce them to dependency. The idea is important, but reasonable self-interest surely goes further. I can keep something back for myself, even if others would get more out of it than I will.

The question whether God could be self-interested in this sense must remain unanswered. However, we have said enough to raise difficulties with the idea that being human requires total suppression of the self, and that this suppression makes us more God-like. Murdoch can sidestep the theological difficulties by discarding God. However, she shares Levinas's antipathy for self-interest, and she retains a version of the claim that the more divine we are the more human we become. Her version of divinity consists in partaking in Goodness. It remains to be seen whether we can find a significant disagreement between them.

\section{BACKTO THE DRAWING BOARD}

Murdoch locates the source of true morality in an austere and unconsoled love of the Good'. ${ }^{90}$ Goodness comes from a beyond which resists all attempts to comprehend it; it can be grasped, if at all, only via our moral dealings with others. Here then, Murdoch says nothing with which Levinas could disagree. Levinas transposes the properties she ascribes to Goodness - invisibility, infinity, and so forth - onto the human other. His intention, we recall, is to capture the sense in which the other opens up a dimension where we can become morally responsive and thus move towards God. Murdoch agrees that Goodness can be 'envisaged' only in practical terms. Yet again then, there is no obvious discrepancy. Crucially, however, Murdoch insists that Goodness is impersonal, even whilst acknowledging that a dissenter might say:

90 “The Sovereignty of Good Over Other Concepts", 92. 
To speak of Good in this portentous manner is simply to speak of the old concept of God in a thin disguise. But at least 'God' could play a real consoling and encouraging role. It makes sense to speak of loving God, a person, but very little sense to speak of loving Good, a concept. 'Good'... is not likely to inspire, or even be comprehensible to, more than a small number of mystically minded people who, being reluctant to surrender 'God', fake up 'Good' in his image, so as to preserve some kind of hope. ${ }^{91}$

Murdoch has little time for a consoling God, nor does Levinas. She resists reserving Goodness for the mystical minority, in favour of a mysticism belonging squarely within the province of any decent human being: it offers 'the least corruptible and most realistic picture for us to use in our reflections upon the moral life'. Levinas is no friend of corruptible pictures, but he refuses to surrender the idea of God. So have we finally identified a substantive disagreement, a disagreement over whether the central concept of morality is to be described in personal terms? This is what Levinas says:

A personal and unique God is not something revealed like an image in a dark room! The text I have just commented upon shows how ethics and principles install a personal relationship worthy of the name. Loving the Torah even more than God means precisely having access to a personal God against Whom one may rebel - that is to say, for whom one may die. ${ }^{92}$

Levinas's God is a personal God, but not a consoling God. God does not manifest Himself as a help. Is He an encouraging God? In one sense, He is not. He becomes present in His absence, and in His absence discourages our love. ${ }^{93}$ But in another sense He is encouraging, for He 'fills us with higher thoughts', and leads us to fulfil our humanity, to become more divine. Again, there is nothing here with which Murdoch could take issue, for she happily allows that we can be divine in this sense. Can we love Him? We can love him, Levinas claims, in the only way possible, namely, by loving the Torah, i.e. by loving His moral demands. This is

\footnotetext{
91 “On 'God' and 'Good', 72.

92 "Loving the Torah more than God", 40. See also "Revelation in the Jewish Tradition", I95-6.

93 "Loving the Torah more than God", 39-40.
} 
surely what Murdoch is getting at when she entertains the possibility of loving Good. Any difference in their positions beyond this point is surely extinguished in that inexhaustible and infinite reality which, as they both believe, must ever elude our grasp.

\section{CONCLUDING THOUGHTS}

Murdoch and Levinas hold that we fulfil our humanity by relating to others morally, and only by so relating do we gain a partial grasp of something whose nature is unknowable. Both figures take themselves to be articulating a true form of religion. They agree also that the 'vision' they offer is austere when placed alongside the more consoling alternatives. Does it matter whether we describe the position in God-involving terms? In one sense, it does not. We can see why Murdoch refuses to do so. The inadequacy of her reasons for refusal might also recommend sympathy for Levinas's terminology. On the other hand, one could protest that his own conception of God is problematic, and his criticisms of Christianity wide of the mark. This gains more credence once we acknowledge his own take on incarnation, and ask whether a further nod in the direction of Christianity would be so disastrous. I suspect not.

Even if we could defend such a move, the question remains whether the position - however we describe it - is correct. I have argued that Murdoch and Levinas are wrong to require total suppression of the self. Does the modification this suggests have important theological implications? Well, it might lead us to reject the demand to become more God-like, if this requires that we become total givers. As I have said, however, what it really means to be God-like is unclear as it stands. And given Murdoch and Levinas's agreement on all the important issues, the advantages and disadvantages of God-talk are negligible.

One way of developing the issue is to ask whether we should accept a form of moral realism, and, if so, whether moral realists should talk like our two protagonists. Murdoch assumes that a morality with no transcendent background can only be 'centred on the individual'. But it remains open that the framework which transcends the individual is the collective product of her community. On this account, morality is 
a collective creation, irreducible to egoism, yet it requires no transcendental background. This gap in her argument can perhaps be closed: First, we can ask why the individual should follow the shared norms of her community. Presumably she will be motivated to do so only if she has respect for others, and if she lacks such respect she will do as she pleases. So, serious participation in the norms of a community presupposes respect for others, and such respect cannot itself be a collective creation. Second, a paradigmatic collective creation is etiquette, and we distinguish etiquette from morality. So, morality is distinguished from what we acknowledge to be collective creations.

This much might lead us towards moral realism, but we are returned to the questions how we are to interpret the transcendence of morality, and whether our protagonists' interpretation is acceptable. They locate the central concept of morality beyond our grasp: Goodness has a transcendent source. Contemporary moral realists allow that there is always room for improvement in our moral beliefs, but few would find the kind of difficulty which would arise if the ultimate object of our moral quest were transcendent in the sense implied by Murdoch and Levinas. ${ }^{94}$ They would also reject the idea that this object is personal, but their reasons, I suspect, would be based upon similar misunderstandings to those we found in Murdoch.

So are there any good reasons for saying that the source of Goodness is transcendent, or, if you prefer, that Goodness itself is transcendent? Murdoch implies that if it is not, then the normative force of morality - the authority of moral requirements - is undermined. Most contemporary moral realists would disagree, although John Cottingham takes this consideration seriously. ${ }^{95}$ Where this leaves us is unclear. But if the present investigation has shown anything it is that we must continue to press such questions and that both sides, or all sides, should be prepared to enter into open-minded dialogue, and to do so without prejudging the issue at the outset by assuming that their opponents are half wits.

${ }^{94}$ For the idea that room for improvement in our beliefs about a given realm is not only compatible with the objectivity of that realm, but a requirement of its objectivity, see Robert S. Tragesser, Phenomenology and Logic (Cornell University Press: Ithaca, NY, I977).

95 "The Source of Goodness", forthcoming. A shorter version of the argument is to be found in Why Believe?, (Continuum Press, London, 2009), ch 2. 
We may not have reached the stage where we can say with confidence that atheism is impossible, but we can surely allow that the possibilities remain open, and that the first step towards progress is to be as clear as we can about the nature of the relevant disagreements. I hope to have shown that one seemingly massive disagreement is really just a matter of semantics. ${ }^{96}$

${ }^{96}$ Thanks to Mike Inwood, Edward Kanterian, John McDade, Gemma Simmonds, and Zita Zigan for inspiration and encouragement. 